\author{
Оксана Чаган \\ Національна академія сухопутних військ імені гетьмана Петра Сагайдачного \\ Львів, Україна \\ ORCID: 000-001-7386-8116; e-mail: oksanachagan@ukr.net
}

\title{
Назви опалювальних споруд та їх конструктивних частин у бойківських говірках
}

\begin{abstract}
Реферат: У статті проаналізовано назви опалювальних споруд та їх частин у контексті дослідження будівельної лексики в бойківських говірках.

Здійснений аналіз ілюструє варіантність лексем на фонетичному, акцентуаційному, словотвірному та граматичному рівнях. Дослідження засвідчує архаїзацію назв опалювальних споруд, що зникли 3 життя бойків у зв'язку зі зміною процесів господарювання. Типовими мотиваційним ознаками для творення назв опалювальних споруд та їх частин у досліджуваних говірках є будівельний матеріал, з якого їх роблять, спосіб розташування споруди чи конструктивної частини стосовно основної, залишковий продукт, який зберігають у цьому місці.

Найпродуктивнішими способами деривації назв опалювальних споруд та їх частин $є$ афіксальний та аналітичний. Серед назв фіксуємо запозичення з польської, німецької, угорської мов, а також зі східнороманських і тюркських мов.
\end{abstract}

Ключові слова: лексема, назви опалювальних споруд, мотивація, бойківські говірки.

\begin{abstract}
Names of heating constructions and their constituent parts in Boycott dialects. The vocabulary of traditional rural construction always reflects the regional culture and customs allowing to reconstruct the history of the material culture of the people as a whole. Heating is one of the most essential typological systems in public dwelling. Research into the heating structures in Boykivshchyna indicates their evolution and improvement resulting in the obsolescence of some and the emergence of new names.

The paper analyses the names of heating structures and their components in the context of research into construction vocabulary.

The analysis illustrates the variability of lexemes at the phonetic, accentuation, word-formation and grammatical levels. The study corroborates the archaisms of heating structures which have vanished due to changes in the lifestyle of the Boykos. Typical motivational signs of generating names of heating structures and their parts in the studied dialects are the respective building materials, the way the structure or its component are positioned in relation to the main structure, and the residuals stored there. The most productive ways of deriving the names of heating structures and their components are the affixed and analytical methods. The names include borrowings from Polish, German, Hungarian, as well as Turkic and Eastern Roman languages.
\end{abstract}

Keywords: lexeme, names of heating structurews, motivation, Boyko dialects.

Важливою складовою традиційної культури етносу є народне житло, а система опалення та відведення диму, на думку дослідника Романа Сілецького, становить одну 3 його найважливіших типологічних особливостей (Сілецький 2008, 134). 
Тому дослідження назв, що репрезентують опалювальні споруди в контексті вивчення будівельної лексики бойківських говірок $є$ актуальним, адже власні польові матеріали підтверджують, що опалювальні споруди як явище матеріальної культури є важливими для повсякденного життя бойків.

Мета пропонованої розвідки - здійснити лексико-семантичний аналіз назв опалювальних споруд та їх частин як сегмента тематичної групи лексики традиційного будівництва в бойківських говірках.

Матеріалом для дослідження слугували власні записи мовлення носіїв бойківських говірок про будівництво житла. Використано також матеріали лексикографічних, лінгвогеографічних та етнографічних праць із Бойківщини.

Опалювальні споруди на Бойківщині пройшли певні етапи еволюції та постійно вдосконалювались: від глинобитної печі до споруд із каменю чи цегли, від курної системи відведення диму до півкурної та споруд зі системою відведення диму понад дах (Радович 2015, 188-191), від споруди, що складалась з єдиної варистої печі для приготування їжі та випікання хліба, до споруд, що мали вже окремі пікні печі та плити для варіння, чи зовсім окремих пристроїв тільки для обігріву (Радович 2015, 198-200).

Досліджуючи лексико-семантичну підгрупу (ЛСП) назв опалювальних споруд в аналізованих говірках, виділяємо загальні назви опалювальних споруд та назви споруд, що мотивовані способом спорудження чи будівельним матеріалом.

Загальними назвами опалюваних споруд є: n’iч (Зкц, Тхк, Хтр, Врх, Мшц, Урч, Анг, Н. Стд, Ялв), пйец (Анг, Здс, Лбх С., Лмн, Н. Ржн, Скл, Ямц), пец (Брк, Всн, Глц Ск., Гсн, Лбн).

Лексема n'iч відома загальнонародній мові (СУМ, VI, 551) та має праслов'янські корені (ЕСУМ, IV, 329). У досліджуваних говірках слово реалізує кілька значення, зокрема: ‘місце на печі, де спали’ (БНП), ‘камера для випікання хліба' (БНП).

Розширену семантичну структуру в бойківських говірках також має лексема nйеu: 'будь-яка опалювальна споруда', 'опалювальна споруда 3 топкою і димоходом, призначених для обігріву, у яких відсутня камера для випікання хліба та місце для приготування їжі', 'камера для випікання хліба (пікна піч)'. За свідченням етимологів, назва запозичена з польської мови; пор.: п. piec 'піч' (ЕСУМ, IV, 366). Слово з ідентичним значенням відоме й іншим говіркам української мови: закарпатським (Дзендзелівський 1958, I, к. 24), лемківським (Пиртей 1986, 284; Горбач, VIII, 615), наддністрянським (Шило 2008, 199; Горбач, V, 69; Бичко 1992, 19), гуцульським (Негрич 2008, 132), західнополіським (Аркушин, II, 43), холмським (Осташ, 373).

Залежно від матеріалу, з якого споруджували піч, та способу будівництва в досліджуваному ареалі фіксуємо назви: 'бита n'iч 'опалювальна споруда, яку роблять шляхом набивання глини' (БНП), біта піч 'тс.' (Ндн) (Радович 2015, 320), n’єu би́ma з гли́ни 'тс.' (В. Сшц) (Радович 2015, 320), (Жкт) (Кобільник $1937,26)$ ma пйец 'опалювальна споруда, яку мурують із цегли' (Анг, Здс, Лбх С., Лмн, Н. Ржн, Скл), пйецуок 'тс.' (Сглт), мур 'тс.'(Анг), муррова 'тс.' (Трвк), му'л'ирка 'тс.' (Скл, Грб), му|л'арка 'тс.' (Крп, С. Мзн), 'кафел'на пеи 'тс.' (Врх), 'кафел'ниц мур 'тс.' (Анг). 
Назви 'бита n'iч, бíma niч, n'єu бúma з гли́ни перейшли до пасивного словника говору у зв'язку зі зникненням реалії з їхнього життя; пор.: лем. битыц пец 'тс.' (Горбач, V, 615).

Лексема мур через посередництво польської запозичена 3 німецької мови (ЕСУМ, III, 535); пор.: мур 'висока кам'яна або цегляна стіна навколо чогось (СУМ, IV, 827). Деривати му|рова, му|л'ирка, му|л'арка коренями сягають, очевидно, теж польського слова mularz 'каменяр, майстер мурування' (ЕСУМ III, 533), 'той, що мурує, будує, вживає за матеріал цеглу, камінь, глину, вапно, цемент' (Karłowicz, II, 1066), що пов'язане з свн. тйге 'стіна, мур' (ЕСУМ III, 533). Релевантною ознакою, на нашу думку, для утворення цих назв є 'кам'яні, цегляні' стіни опалювальних споруд; пор.: гуц. мульи́рка 'будування з цегли або каменю' (Негрич 2008, 117), зх.поліс. мур 'мурована 3 цегли грубка, піч і простінки в хаті' (Аркушин, II, 323).

Складені назви |кафел'ниц мур, 'кафел'на пеи вказують на матеріал, який використовують для їхнього облицювання; пор.: ка́хлі 'керамічні плитки для личкування печей, стін будівель і т. ін.' (СУМ, IV, 122).

Зміна способу господарювання та технологічних процесів спричинила появу опалювальних споруд із топкою й димоходом, призначених для обігріву, у яких немає камери для випікання хліба та місця для приготування їжі. На позначення таких споруд у бойківських говірках фіксуємо назви об’ігр'ilвач (Н. Крп), обогр'івач (Врх), огр'iвач (Сглт, Мт, Здс, Урч), вогр'івач (Брк, Грз, Лмн, Лбх Т., Мшц, Сглт,), 'кафел'ниц пеи (Глц Ск.), 'кафел'ниц пйец (Ялн), 'кафл'і (Ялв), пйеи (Імн, Клн, Крп, С. Мзн, Урч, Хтр), пйецьок (Крк, Н. Ржн, Скл), стойак (Глц Ск., Лбх Т., Грз), 'кал'га (Всн), три'л'аж (Грб), грубка (Ясн).

Лексема об'ігр'iвач та однокореневі слова мають прозору мотивацію вказують на функцію денотата; пор.: обігріва́ч 'пристрій, прилад для обігрівання' (СУМ, V, 502).

Назва стойак, очевидно, мотивована способом розташування пристрою у вертикальному положенні; пор.: стоя'к 'вертикальний брус, стовп, який служить опорою для чого-небудь, у якійсь споруді', 'пристрій для підтримання та зберігання яких-небудь предметів у стоячому положенні’ (СУМ, IX, 741). Лексема має праслов’янські корені (ЕСУМ V, 430); пор.: нддніс. стоя'к 'груба, піч’ (Шило 2008, 246), лем. стояк 'опора моста або греблі' (Пиртей 1986, 371), біл. діал. стаяк 'комин' (Янкова 1982, 340).

Не зовсім ясне походження лексеми 'кал'га. У закарпатських говірках слово Ікал'га відоме зі значенням 'груба, грубка' (Сабадош 2008, 138). У літературній українській мові зафіксована назва |кагла 'отвір у димоході (до стелі), який затуляють для збереження тепла тощо’ (CУM, IV, 68), яка, за свідченням етимологів, є давнім видозміненим запозиченням з німецької мови; пор.: снн. kacheloven 'вид печі із глиняним склепінням і заглибленням, що збільшувало площу нагрівання' (ЕСУМ, II, 337); п. kahła 'комин, отвір до комина; отвір в хаті курній' (Karłowicz, II, 202). Можна також пов’язувати назву 'кал'га $з$ угорським словом kályha 'піч, пічка' (Гальді 1987, 346; Сабадош 2008, 138).

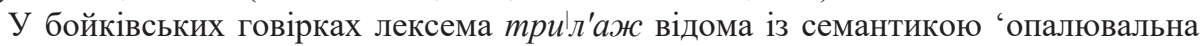
споруда з грубкою і димоходом, що має три кути’. Мотиватором назви, очевидно, 
$\epsilon$ форма споруди, оскільки має три кути, де в інших спорудах, зазвичай, чотири кути. Загальнонародній мові відоме слово трелья́ж, одне зі значень якого ‘тристулкове дзеркало' (СУМ, Х, 242). Етимологи вважають, що значення ‘тристулкове дзеркало' у запозиченого з французької мови слова treillage 'альтанка' виникло на грунті російської мови в результаті народноетимологічного переосмислення за аналогією до треуго́льник, трено́жнік (ЕСУМ, V, 628).

Лексема г'рубка є демінутивом від літературної назви гру́ба 'піч, що служить для опалювання приміщення’ (СУМ, II, 177), яку вважають запозиченням з польської мови (п. gruba 'велика піч; копальня') (ЕСУМ, I, 602); пор.: зх.поліс. гру́бка 'мала піч' (Горбач, V, 289), сх.под. груба 'висока вертикальна піч, що служить для опалювання приміщення’ (Поліщук 2015, 254).

У досліджуваній ЛСП виділяємо лексико-семантичну мікрогрупу (ЛСМ) назв конструктивних частин опалювальних споруд.

3і значенням 'камера для випікання хліба (пікна піч)' фіксуємо назви n'iч (БНП), Іпекарс'ка п’iч (Сглт), пец (Врх), пйец (Ндн, Сшц, Тпц, Тр’є), що в досліджуваних говірках $є$ багатозначними, зокрема репрезентують значення 'опалювальна споруда (загальне значення)', пор. лем. пец 'піч, у якій печуть хліб, варять їсти; верх печі, де сплять та вигріваються взимку’ (Турчин 2001, 232).

У бойківських говірках на позначення нижньої площини, дна печі, де горять дрова й випікають хліб найбільш уживані є слова 'ватра (Анг, Бгт, Брк, Бтл, Всн, Грв, Грз, Глц Ск., Жкт, Жпн, Зкц, Здс, Ісї, Імн, Клн, Крк, Крп, Лбх С., Лбх Т., Лмн, Лсц, Мшц, Мт, Н. Ржн, Плв, Пбк, Рлч, Сглт, С. Мзн, Сшц, Тпц, Хтр, Хщв, Хщн, Ябл, Ялв, Ялн), (Ндн, Спс, Тр'є, Тсц) (Радович 2015, 321; Фальковські $1935,22)$. Оказіонально фіксуємо також слово Ічер'ін' (Грбн).

Лексема 'ватра 'вогнище, багаття' зафіксована в СУМі з приміткою 'діалектне' (СУМ, I, 297). Значення слова ватра 'дно печі, на якому печеться хліб’ зафіксоване в інших лексикографічних працях (Грінченко, I, 129; Желехівський, I, 57). Мотивацією для творення слова $\epsilon$, очевидно, вогонь, який розкладають на дні печі. У бойківських говірках слово багатозначне: 'черінь'; 'вогонь'; 'купа розжареного вугілля’; ‘вогнище в полі, лісі'; ‘місце, де горів вогонь'; ‘родовий маєток’ (Онишкевич, I, 86). Не зовсім ясна етимологія слова. Дехто з дослідників уважає його спільнослов'янським, проте висловлюють i думку про запозичення 3 давньоіранської мови через посередництво турецької чи циганської; також припускають, що слово має румунські корені (ЕСУМ, I, 339). Ареал поширення назви 'ватра 'дно печі, на якому печеться хліб' продовжується в інших говірках української мови: наддністрянських (Шило 2008, 67), лемківських (Пиртей 1986, 40), буковинських (СБГ 2005, 48), у говірках Одещини (Бондарь 2010, 36). Карти Загальнокарпатського діалектологічного атласу ілюструють функціювання слова 'ватра із цим значенням також у говорах Польщі, Словаччини, Румунії, Молдови (ЗКДА, I, к. 55).

Назва 'чер'ін' із семантикою 'дно печі, на якому печеться хліб' зафіксована у відомих лексикографічних працях (СУМ, XI, 308; Грінченко, IV, 457; Желехівський, II, 1067). За свідченням етимологів, слово має праслов'янські корені (ЕСУМ, VI, 306). У говірках української мови назва 'че(u)()p'iн' відома з різними значеннями: гуц. 'стеля в печі' (Піпаш 2005, 219), нддніс. 'місце на печі, де 
зазвичай сидять діти' (Шило 2008, 273), бук. 'багаття, вогнище', 'припічок', 'черінь, дно печі' (СБГ 2005, 48), зх.поліс. 'місце в печі, де горять дрова; найгарячіше місце зверху , де лягали колись спати’ (Аркушин, II, 249; Свтушок 1993, к. 58; Горбач, V, 324), пн.добрудж. 'дно печі хлібної' (Горбач, V, 399), сх. поділ. 'нижня площина, дно печі' (Поліщук 2015, 301), холм. 'дно печі' (Осташ 2004, 377).

Значення 'верхнє внутрішнє опукле перекриття печі' у досліджуваних говірках репрезентоване назвами скле'n’iн'a (Крп, Н. Крп, С. Мзн), склел'ін'е (В. Сшц, Ндн) (Радович 2015, 321), склеп'н'ін'a (Брк), склепл'ін'a (Зкц), склепл'i н'a (Анг), склеп' л'н'е (Тр'є) (Радович 2015, с. 321), склеп' 'ін': а (Грз, Імн), склеп (Ялв), (Тсц) (Радович 2015, 321), n'iднеб'ін'а (Брк, Зкц), n’iднебин'а (Плв, Псп, Сглт, Хщв), n'iднебен'е (Ксв, Ямц), n’iднеб'ін':a (Грз, Здс, Крк, Лмн, Мшц, Урч), (Жкн) (Кобільник 1937, 26), піднебя (Фальковські 1935, 22), 'небо (Анг, Клн, Н. Стд, Хтр, Хщн).

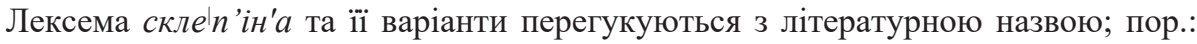
скле піння 'опукле перекриття або покриття, що з'єднує стіни, підпори будівель, споруд, мостів і т. ін.; опукла стеля або взагалі верхнє внутрішнє покриття' (СУМ, IX, 280; Грінченко, IV, 137; Желехівський, II, 874); Слово склеn у досліджуваних говірках - реалізує кілька значень: 'сховище для зберігання городини та інших їстівних припасів зі склепінчастим перекиттям', 'сховище для городини ямного типу із плоским перекриттям з лядою без східців та двосхилим дахом', 'приміщення під першим поверхом будинку нижче рівня землі для зберігання городини та інших їстівних припасів'); пор.: склеп 'те саме, що склепіння' (СУМ, IX, 279). За свідченням етимологів, назва склепіння походить від запозиченого з польської мови слова sklep 'підвал, льох, шинок', яка зводиться до псл. *sъklepъ 'прикриття' (ЕСУМ, V, 274); пор.: зх.поліс. склепін':a, склеn, склепова́н'н'е, скл'іпова́н'н'е 'тс.' (Свтушок 1993, к. 55; Горбач, V, 319), бук.

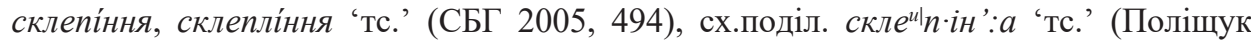
2015, 336).

Уживання лексеми $n$ 'idнебб'ін:' $a$ і їі варіантів зі значенням 'верхнє внутрішнє опукле перекриття печі', очевидно, зумовлене метафоричним перенесенням за схожістю форми; пор.: піднебіння 'верхня стінка ротової порожнини у людей і хребетних тварин, яка поділяється на передню тверду й задню м’яку частини і має склепінчасту форму’ (СУМ, VI, 461; Желехівський, II, 645). Як стверджують етимологи, назва піднебі́ння є похідною від назви не́бо (ЕСУМ, IV, 57).

Функціювання лексеми 'небо зі значенням 'верхнє внутрішнє опукле перекриття печі', очевидно, також зумовлене метафоричним перенесенням за схожістю форми; пор.: не́бо 'видимий над поверхнею землі повітряний простір у формі купола' (СУМ, V, 249); пор.: рос. нёбо 'верхня стінка порожнини рота, що має склепінчасту форму' (БТС); пор. також: пд.вол. піднебін'н'е 'т.с.' (Горбач, V, c. 492), зх.поліс. поднебін': а, небо 'склепіння над черінню печі' (Свтушок 1993,

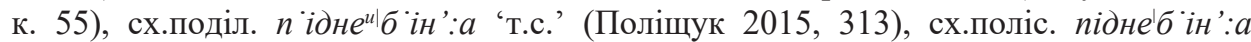
'т.с.' (Дорошенко 1999, к. 91), біл. діал. не́ба 'тс.' (Янкова 1982, 214).

Отвір дугастої форми між припічком і внутрішньою частиною у бойківських говірках номіновано: ччел'усти (Брк, Здс, Зкц, Лбх С., Лбх Т., Мшц, Ндн, Сглт), 
(Фальковські 1935, 22), 'чел'уст'i (Глц Ск., Крк), 'чил'ус'm'i (Врх). Назва челюсті відома також у літературній мові (СУМ, ХІ, 291) та засвідчена в лексикографічних працях (Грінченко, IV, 450; Желехівський, II, 1063). Як стверджують етимологи, слово че́люсті виникло як складний новотвір на праслов'янському грунті (>čelъ вid čelo (укр. чолó) та - ust- від usta (укр. yста́) (ЕСУM, VI, 292); пор.: лем. челюсти 'вхід до печі' (Пиртей 1986, 430), чел'ycm' 'півкруглий отвір хлібної печі' (Горбач, V, 647), нддніс. че́ліста, че́люста, че́люства 'челюсть печі' (Шило 2008, 272), че́л'уста, че́л'yсти 'горішня частина отвору хлібної печі' (Горбач, V, 96), пд.вол. че́л'ус'и’i 'отвір хлібної печі' (Горбач, V, 517), зх.поліс. чел'усті, чел'уст' 'т.с.' (Свтушок 1993, к. 54; Горбач, V, 324), сх.поділ. 'чел'yc'm 'i 'внутрішнє опукле верхнє покриття над черінню; місце в печі, куди загрібають жар’ (Поліщук 2015, 362).

Значення 'площина перед челюстями печі під комином' репрезентована назвами npun’iч (Здс, Лбх С., Орв, Тхк) nрип'ічок (Анг, Брк., Врх, Всн, Зкц, Імн, Крк, Крп, Мшц, Ндн, Опр, Сглт, Скл, С. Мзн, Тсц, Тр’є, Хтр, Ялв), при' ’ічок (Глц Ск., Грбн, Ісї, Кмк, Лбх Т, Лмн, Мшц, Псп, Рлч, Хщв). Мотивація назви прозора, адже вказує на розміщення окремої частини стосовно печі. Із таким самим значенням слово при́пічок зафіксовано в літературній мові (СУМ, VII, 709) та інших лексикографічних працях (Грінченко, III, 432; Желехівський, II, 753).

На позначення ніші між стіною і піччю, де зберігали різні речі чи спали, у досліджуваних говірках виявляємо слова заң' ’чок (Брк, Глц Ск., Сглт), Ізаn'ічок (Анг, Врх, Крк, Крп, Лбх С., Лмн, Мшц, Ндн, Н. Ржн, С. Мзн, Хтр, Ялв). Мотиватором назви виступає місце розташування реалії стосовно печі. У бойківських говірках слово багатозначне: ‘лавка або нари між стіною і піччю’, ‘лавка під піччю', 'заглиблення в печі для посуду зі сіллю', 'верхня частина печі за кухонною плитою, де взимку сплять', 'місце між ліжком і піччю' (Онишкевич, I, 280). Лексема за́n’iчок 'місце на печі, відгороджене комином, або за піччю', 'різної величини заглибина в бічній, задній або передній стіні печі, де зберігають предмети домашнього вжитку, продукти' (СУМ, III, 261), 'місце на печі (де лежать)' (Грінченко, II, 80) є нормативною для української мови; пор.: лем. запеиок ‘запічок'; лава за піччю паралельно до пекарської печі' (Пиртей 1986, 121), нддніс. за'n 'єu, за'n'єuук 'запічок' (Шило 2008, 123), гуц. за́пічок 'лежанка на печі чи біля печі' (Піпаш 2005, 63), пд.вол. за́пічок 'поріг, щоб вилізти на пікну піч' (Горбач, V, 457), зх.пол. за́пик, за́пич 'запічок’ (Горбач, V, 293), біл. діал. за́печок 'тс.' (Янкова 1982, 127).

Верхню площину печі, де сплять та вигріваються взимку в бойківських говірках номіновано: Номінацією для верхньої площини печі є лексеми n'iч (БНП), Ілежанка (Грбн), лежанка (Врх), топччан (Глц Ск.), пйеи (Ндн).

Назва Іле()жанка має прозору мотивацію. Зі схожими значеннями відома літературній мові: лежа́нка 'низька піч у вигляді тапчана для лежання', ‘призначене для лежання, спання підвищення з дерева, глини тощо’ (СУМ, IV, 469). Слово відоме іншим говіркам української мови: зх.поліс. п еч-лежанка 'місце над піччю, де можна спати, сушити зерно' (Євтушок 1993, к. 58), говіркам Черкащини - лижжнка 'місце на печі, на якому лежать' (ГЧ 2013, 372), говіркам Одещини - ліжа́нка, лежанка 'припічок для спання, під яким порожнина сполучена з грубою’ (Мельничук 1958, 84). 
Уживання лексеми топчан зі значенням 'верхня площина печі, де сплять та вигріваються взимку', очевидно, пов’язано зі схожістю функції, яку виконує ця частина споруди, з літературною назвою тапча́н 'вид ліжка 3 дощок без спинок' (СУМ, X, 37; Грінченко, IV, 246). Етимологи вказують на тюркське походження слова (ЕСУМ, V, 516); пор.: лем. тапчан 'тапчан, прича; вид широкого ліжка без спинок; широка лава для спання’ (Пиртей 1986, 382).

Як стверджують етнологи, на початку XX ст. на Бойківщини інтенсивно відбувається поділ функцій печі: пікну піч «використовують для випікання хлібних виробів, а для варіння прибудовують грубку з плитою» та в комплексі печі з'являється духовка (Радович 2015, 199). Відповідно у ЛСМ назв конструктивних частин опалювальних споруд виявляємо лексеми 'кухн'а (БНП), 'кухн'i (Скл, Грб), шпор (Ялв, Н. Стд), шпардет (Гсн, Всн, Лбн) із семантикою 'груба, накрита чавунною плитою для приготування страв'.

Лексема 'кухн'a має прозору мотивацію, вказуючи на функційне призначення реалії пор.: 'кухн'a 'спеціально пристосоване приміщення з піччю, плитою і т. ін. для готування їжі; набір страв, характер харчування’ (СУМ, IV, 420). На думку етимологів, слово запозичене з польської мови, куди, очевидно, потрапило з німецької; пор.: свн. küchen (> нвн. Küche) 'тс.'; пор.: гуц. кýxн'i 'піч для приготування їжі' (Негрич 2008, 103), лем. кухн'а 'тс' (Горбач 1993, V, 596), бук. кýxн'а, кýхн'є 'плита; кухня' (СБГ 2005, 245).

Назви шиар гет та шпор розглядають-як запозичення з німецької мови (ЕСУМ, VI, 458). За твердженням Й. Дзендзелівського, обидва слова є однокореневими та, очевидно, запозичені за посередництвом угорської мови; пор.: слц. діал. šporhért, угор. діал. sparhét, угор. діал. spór 'тс.' (Дзендзелівський 1958, к. 25); пор. також: закарп. шпор 'кухонна плита' (Сабадош 2008, 423), лем. шпаргет 'тс.' (Пиртей 1986, 347).

Із семантикою 'залізний ящик, вставлений у печі, щоб зберігати їжу теплою' фіксуємо лексеми брайдура (Брк, Врх), брайтура (Глц Ск.), духхоўка (Глц Ск, Грз, Імн, Лмн, Мшц, Урч), братрура (Анг, Грв, Грбн, Імн, Крп, С. Мзн, Урч, Ямц), брандура (Зкц, Рзч), бра тура (Н. Ржн, Сглт, Скл, Урч, Хтр), брацура (Бтл, Крк, Лбх Т., Лмн, Рзч), брадрура (Грз, Мшц, Н. Крп), братрура (Лсц), б л оўдар' (Ялв).

Назва ду|хоўка, на думку етимологів, запозичена з російської мови (ЕСУМ, II, 150); пор.: літ. 'тс.' (СУМ, II, 444).

Лексема братрура та ㄲi варіанти, як стверджують етимологи, запозичені 3 німецької мови за польським посередництвом (п. bratrura > нвн. Brátröhre 'піч для розігрівання; маленька піч для піджарювання’) (ЕСУМ, I, 249). Ідентичне значення слово має в інших говірках української мови: нддніс. брадру́ра, брайру́ра, братви́ра, братри́ра (Шило 2008, 58; Горбач 1993, V, 27), гуц. братру́ра (Негрич 2008, 28), лем. брадрура (Пиртей 1986, 32; Турчин 2011, 31), бук. братру́ра, братри́ла, брату́ра (СБГ 2005, 38; Горбач 1977, VIII, 142), п. діал. bratruła (Nowak 2015, 191; SGP, I, 475).

Назва б лоудар', припускаємо, може бути запозичена з німецької мови через угорське посередництво; пор.: закарп. блу́дер 'духовка в кухонній плиті' (Сабадош 2008, 27), угор. діал. blouder 'тс', нім. діал. Brouder 'тс.'. Слово бро́дер 'духовка' відоме й у гуцульських говірках (Піпаш 2005, 17). 
На позначення місця, куди випадає попіл під кухнею, грубою в досліджуваних говірках виявляємо лексеми поп'іл'ник (Брк, Бтл, Врх, Псп, Сглт, Ясн), поп 'ї̆ник (Псп), 'поп 'іл'ник (Лмн), попе('i)|'л'арка (Грз, Грб, Мшц), попе('i)|л'анка (Всн, Лсц), nоn'іл"ниц'а (Зкц), поп'іл"ничка (Анг, Жкт, Імн, Крк, Н. Крк), Іп'ічка (Здс, Імн, Скл, Урч, Хтр), n’iч'ниц'а (Зкц), пе цуоука (Ялв), 'коўбашка (Глц С.), спу'зарка (Крп, С. Мзн).

Похідні утворення від слова по́піл на позначення місця, куди випадає попіл під кухнею, грубою мають праслов'янські корені (ЕСУМ, IV, 517) та відомі іншим говірковим ареалам української мови: лем. попел'ник 'піддувало, місце для попелу під решіткою грубки’ (Турчин 2011, 251; Пиртей 1986, 305), нддніс. попільни́к ‘піддувало, куди через решітку сиплеться попіл' (Шило 2008, 213), пд.бук. попіл'ни́чка 'грубка на попіл' (Горбач, VIII, 203). Демінутиви In'ічка, n'iчниц'a та пециоўка, очевидно, утворені шляхом метонімічного перенесення із цілого на його частину (n’iч, nеu - опалювальна споруда).

Затемнену мотивацію має назва 'коўбашка. Можливо, пов'язана з літературною назвою ковба́ня 'глибока вибоїна, звичайно на дорозі, переважно з водою, болотом; глибоке місце, яма в річці, озері тощо’ (СУМ, IV, 202; Грінченко, II, 260) чи ко́вбиця 'отвір у передній частині селянської печі' (СУМ, IV, 203). Етимологи розглядають слово як складне утворення від псл. kolo 'колесо' або псл. kol- 'колоти, бити' та псл. banja 'копальня; яма, заглибина' (ЕСУМ, II, 480); пор.: нддніс. ко́вбиці 'заглибина під припічком: місце в комині, де коптять ковбаси' (Шило 2008, 145), гуц. ковба́н'и 'яма, заповнена водою' (Піпаш 2005, 80), сх.под. коўбашка 'заглиблення в задній стіні печі, куди ставлять ногу, щоб легше було вилазити на піч’ (Поліщук 2015, 281), говірки Одещини - ко́вбиця, ко́вбичка 'запічок' (Бондарь 2010, 101).

Мотивацію назви спуззарка, очевидно, теж є продукт згорання дров. У СУМі iз ремаркою “діалектне” зафіксовано назву сnуз 'попіл, присок' та спуза́p 'пастух, в обов’язки якого входить підтримувати вогонь, заготовляти дрова, носити воду’ (СУМ, IX, с. 611). У бойківських говірках також виявлено сnýза, сnýdза 'попіл; попіл із вогнем; попіл зі сажею' (Онишкевич, II, 246). За твердженням етимологів, слово сnи́за запозичено зі східнороманських мов (рум. spúză 'гарячий попіл 3 жаром; попіл', молд. спи́зэ 'тс.' (ЕСУМ, V, 386); пор.: гуц. спи́за 'порох, пил', cnуза́рь 'палиця для перегортання жару' (Негрич 2008, 162; Піпаш 2005, 182), бук. сnу́за 'попіл зі соломи, паперу, різного бадилля, який легко піднімається вгору, а потім осідає; сажа', спуза́p 'пастух, в обов 'язки якого входить підтримувати вогонь, заготовляти дрова, носити воду’ (СБГ 2005, 516).

Репрезентантами значення 'металева решітка під грубою чи кухонною плитою, через які випадає жар та попіл’ виступають назви 'рушта (Анг, Брк, Глц Ск, Грб, Здс, Зкц, Н. Крп, Скл, Хтр, Ямц), рушта (Крп, С. Мзн), 'рошта (Всн), г'ратка (Грз), граткы (Мшц), ре ш'ітка (Ялв).

Лексема рушта, як стверджують етимологи, запозичена 3 польської мови (п. ruszt, roszt 'грати, решітка', що походить від нім. Rost 'грати; колосники') (ЕСУМ, V, 151). Із цим значенням слово поширене в інших говірках: гуцульських (Негрич 2008, 154), лемківських (Пиртей 1986, 347), буковинських (СБГ 2005, 472). 
Отже, аналіз ЛСП назв опалювальних споруд та їх частин у бойківських говірках засвідчив варіантність на фонетичному: (n(ü)eu, мул'и(a)pка, би(i)ma

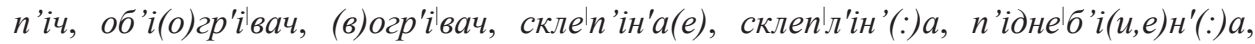
чче(и)р'ін', Іче(и)л'усти('i), брайд(m)ура, брат(д,г)|рура, браныдура, бра'т(д)ура); акцентуаційному - ('поп'іл'ник, 'лежсанка, склеп'л'і'н'a), словотвірному (склеп -

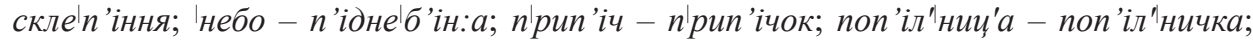
попе('i)!л'анка - попе('i)!л'арка; 'n'ічка - n'iч'ниц' a); граматичному - ('кафел'ний пец - 'кафел'на пец, г'ратка - г'раткы) рівнях.

Типовими мотиваційним ознаками для аналізованої ЛСП $є$ назви будівельного матеріалу, з якого їх споруджують, спосіб розташування власне споруди чи конструктивної частини стосовно основної, залишковий продукт, який зберігається в цьому місці.

Найпродуктивніші способи деривації назв такі: афіксальний (суфіксальний -к- (му'л'и(а)рка, ле'жанка, г'рубка, 'коуббашка, попі'л'арка, попі'л'анка, спу'зарка,

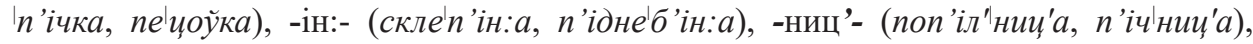
префіксально-суфіксальним ('запічок, припічок), аналітична номінація ('пекарс'ка n’iч, бита n’iч, бі́mа піч, пйеи бйта з гли́ни, Ікафел'ний пец 'кафел'ний пйец, 'кафел'ниц мур), запозичення $з$ інших мов (польської - пйец, братірура, склеп, угорської - шпор, шпартет, бловдар', німецької - мур, кагла, російської три'л'аж).

\section{Список обстежених населених пунктів і їхніх скорочень}

БНП - Більшість населених пунктів; Анг - Ангелівка, Долинський р-н, Івано-Франківська обл.; Бгт - Багнувате, Турківський р-н; Брк - Боберка, Турківський p-н, Львівська обл.; Бтл - Бітля, Турківський р-н, Львівська обл.; В. Сшц. - Велика Сушиця, Старосамбірський p-н, Львівська обл.; Всн - Волосянка, Великоберезнянський р-н, Закарпатська обл; Врх - Верхнє, Турківський p-н, Львівська обл.; Глц Ск. - Головецько, Сколівський р-н, Львівська обл.; Грб Грабів, Рожнятівський р-н, Івано-Франківська обл.; Грбн - Гребенів, Сколівський p-н, Львіська обл.; Грз - Грозьова, Старосамбірський р-н, Львівська обл.; Гсн Гусний, Великоберезнянський р-н, Закарпатська обл.; Жкт - Жукотин, Турківський p-н, Львіська обл.; Жпн - Жупани, Сколівський р-н, Львівська обл.; Зкц - Закіпці, Турківський р-н, Львіська обл.;Здс - Задільське, Сколівський р-н, Львівська обл.; Ісї - Iсаї, Турківський р-н, Львівська обл.; Імн - Ілемня, Рожнятівський p-н, Івано-Франківська обл.; Клн - Кальне, Сколівський р-н, Львівська обл.; Кмк Комарники, Турківський р-н, Львіська обл.; Крк - Кривка, Турківський р-н, Львівська обл; Крп - Кропивник, Долинський р-н, Івано-Франківська обл.; Ксв Коростів, Сколівський р-н, Львівська обл.; Лбн - Лубня, Великоберезнянський p-н, Закарпатська обл.; Лз - Лази, Воловецький p-н, Закарпатська обл.; Лмн Лімна, Турківський р-н, Львівська обл.; Лбх С. - Либохора, Турківсикий p-н, Львівська обл.; Лбх Т. - Либохора, Турківський р-, Львівська обл.; Лсц - Лосинець, Турківський р-н, Львівська обл.; Мт - Мита, Сколівський р-н, Львівська обл.; 
Мшц - Мшанець, Старсомбірський р-н; Ндн - Недільна, Старосамбірський р-н, Львівська обл.; Н. Крп - Новий Кропивник, Дрогобицький р-н, Львівська обл.; Н. Ржн - Нижня Рожанка, Сколівський р-н, Львівська обл.; Н. Стд - Нижній Студений, Міжгірський р-н, Закарпатська обл.; Орв - Орів, Сколівський р-н, Львівська обл.; Пбк - Побук, Сколівський р-н, Львівська обл.; Плв - Плав’є, Сколівський р-н, Львівська обл.; Псп - Присліп, Турківський р-н, Львівська обл.; Рлч - Розлуч, Турківський р-н, Львівська обл.; Сглт - Сигловате, Турківський р-н, Львівська обл.; Скл - Сукіль, Долинський р-н, Івано-Франківська обл.; С. Мзн Старий Мізунь, Долинський р-н, Івано-Франківська обл., Спс - Спас, Старосамбірський р-н, Львівська обл.; Сшц - Сушиця, Старосамбірський p-н, Львівська обл.; Тпл - Топольниця, Старосамбірський р-н; Трвк - Тернавка, Сколівський р-н, Львівська обл.; Тр'є - Тур'є, Старосамбірський р-н, Львівська обл.; Тсц - Тисовиця, Старосамбірський р-н, Львівська обл.; Тхк - Тухолька, Сколівський р-н, Львівська обл.; Урч - Урич, Сколівський р-н, Львівська обл.; Хщв - Хащів, Турківський р-н, Львівська обл.; Хщн - Хащованя, Сколівський p-н, Львівська обл.; Хтр - Хітар, Сколівський р-н, Львівська обл; Ябл - Яблунів, Турківський р-н, Львівська обл.; Ялв - Ялове, Воловецький р-н, Закарпатська обл.; Ялн - Ялинкувате, Сколівський р-н, Львівська обл.; Ямц - Ямельниця, Сколівський р-н, Львівська обл.; Ясн - Ясень, Рожнятівський p-н, ІваноФранківська обл.

\section{Література}

Аркушин Г.Л. [Arkushyn, H.L.] (2000), Словник західнополіських говірок, [Slovnyk zakhidnopoliskykh hovirok, т. 1-2, Луцьк.

Бичко 3.M. [Bychko Z. М.] (1992), Словник діалектної лексики села Грабовецьь Стрийського p-ну Львівської обл. Матеріали до вивчення курсу «Українська діалектологія» [Slownyk dialektnoi leksyky sela Hrabovets Stryiskoho rayonu Lvivskoi oblasti. Materialy do vyvchennia kursu «Ukrainska dialektolohia»], Львів.

Бондарь O.I. [Bondar O.I.] (ред.) (2010), Словник украӥнських говорів Одещчини, [Slovnуk ukrainskykh hovoriv Odeshchyny], Одеса.

БТС, Большой толковый словарь русского языка [Bolshoi tolkovyi slovar ruskoho yazyka] (1998), гл. ред. С.А. Кузнецов [S.A. Kuznetsov], публикуется в авторской редакции 2014 года, http: gramota.ru/ slovari/info/bts.

Гальді, Венгерско-русский словарь [Vengersko-ruskyi slovar], общ. ред. Л. Гальді (L. Haldi), Москва, Будапешт 1987.

Грінченко (1907-1909), Словарь української мови [Slovar ukrainskoi movy], упоряд. 3 доданням власного матеріалу Б. Грінченко, [В. Hrinchenko.), т. 1-4, Київ.

Горбач О. [Horbach O.] (1977), Зібрані cmammi [Zibrani statti], т. VIII: Iсторія мови. Діялектологія. Лексикологія [Istoriia movy. Dialektolohiia. Leksykolohiia], Мюнхен.

Горбач O. [Horbach O.] (1993), Зібрані cmammi [Zibrani statti], т. V: Діялектологія [Dialektolohiia], Мюнхен.

ГЧ, Говірки Черкашини. Збірник діалектних текстів [Hovirky Cherkashchyny. Zbirnyk dialektnych tekstiv], упорядн. Г.I. Мартинова, Т.В. Щербина, А.А. Таран [H.I. Martynova, T.V. Shcherbyna, A.A. Taran), Черкаси 2013. 
Дзендзелівський Й.О. [Dzendzelovskyi Y.О.] (1958-1993), Лінгвістичний атлас украӥнських народних говорів Закарпатської області УРСР: Лексика [Linhvistychnyi atlas ukrainskykh narodnykh hovoriv Zakarpatskoi oblasti URSR: Leksyka], ч. I, Ужгород.

Дорошенко Л.I. [Doroshenko, L.I.] (1999), Ареалогія будівельної лексики східнополіського діалекту: дис. ... канд. філол. наук [Arealohiia budivelnoi leksyky skhidnopoliskoho dialektu: Avtoref. dys. ... kand. filol. nauk]: 10.02.01, Київ.

ЕСУМ, Етимологічний словник української мови [Etymolohichnyi slovnyk ukrainskoi movy], т. 1-6, Київ 1982-2012.

Євтушок O.M. [Yevtushok, O.M.] (1993), Атлас будівельної лексики Західного Полісся [Atlas budivelnoi leksyky Zakhidnoho Polissia], Рівне.

Желехівський Є., Недільський С. [Zhelehivsky E., Nedilsky S.] (1886), Малоруско-німеикий словар [Malorusko-nimetskyi slovar), т. 1-2, Львів.

ЗКДА, Общекарпатский диалектологический атлас [Obshchekarpatskyi dialektolohycheskyi atlas), вып. 1, Кишенев 1989.

Кобільник В. [Kobilnik, V.] (1937), Матеріяльна культура села Жукотин Турчанського noвimy [Materialna kultura sela Zhukotyn Turchanskoho povitu], «Літопис Бойківщини», вип. 7 , с. $15-37$.

Мельничук O.C. [Melnychuk O. S.] (1958), Словник специфічної лексики говірки села Писарівка (Кодимський р-н, Одеська обл.) [Slovnyk spetsyfichnoi leksyky hovirky sela Pysarivka (Kodymskyi r-n, Odeska obl.)], «Лексикографічний бюлетень», вип. 6, с. 67-98.

Негрич М. [Negrych M.] (2008), Скарби гуиульського говору: Березови́ [Skarby hutsulskoho hovoru: Berezovú), відп. ред. Н. Хобзей [N. Khobzey], Львів.

Онишкевич М.Й. [Onyshkevych M.I.] (1984), Словник бойківських говірок [Slovnyk boikivskykh hovirok], т. 1-2, Київ.

Осташ Н. [Ostash N.] (2004), Словник діалектної лексики переселенців із Холмщиини [Slovnуk dialektnoyi leksyky pereselentsiv iz Kholmshchyny), [в:] Діалектологічні студіï [Dialektologichni studii], 4: Школи, постаті, проблеми [Shkoli, postati, problemy], відп. ред. П. Гриценко, Н. Хобзей [P. Hrycenko, N, Khobzey], Львів, с. 355-378.

Піпаш Ю.О., Галас Б.К. [Pipash Y. О., Galas В.К.] (2005), Матеріали до словника гуиульських говорів (Косівська Поляна і Росішка Рахівського району Закарпатської області) [Materialy do slovnyka hutsulskykh hovoriv (Kosivska Poliana i Rosishka Rakhivskoho raionu Zakarpatskoi oblasti)], Ужгород.

Пиртей П.С. [Pyrtei, Р. S.] (2004), Короткий словник лемківських говірок [Korotkyi slovnyk lemkivskykh hovirok), Івано-Франківськ.

Поліщук Л.Б. [Polishchuk, L В.] (2015), Структурна організаиія та географія назв традииійного будівництва в східноподільських говірках: дис. на здобуття наук. ступеня канд. філол. наук: спец [Strukturna orhanizatsiia ta heohrafia nazv tradytsiinoho budivnytstva $v$ skhidnopodilskykh hovirkakh: dis. ... kand. filol. nauk], 10.02.01, «Українська мова».

Радович P. [Radovich R.] (2015), Народна архітектура Старосамбірщини XIX - першої половини XX cm. (Житлово-господарський комплекс) [Narodna arkhitektura Starosambirshchyny XIX - pershoyi polovyny XX st. [Zhytlovo-hospodars'kyy kompleks)], Київ.

Сабадош I.B. [Sabadosh I.V.] (2008), Словник закарпатської говірки села Сокирниия Хустського району [Slovnyk zakarpatskoi hovirky sela Sokyrnytsia Khustskoho raionu], Ужгород. 
СБГ, Словник буковинських говірок [Slovnyk bukovynskykh hovirok), заг. ред. Н.В. Гуйванюк [N.V. Huyvanyuk], Чернівці 2005.

Сілецький P. [Siletskyi R.] (2008), Опалювальні пристрої народного житла Середнього Полісся (конструктивно-функціональний та світоглядний аспекти) [Opaliuvalni prystroi narodnoho zhytla Seredn'oho Polissia (konstruktuvno-funtsionalyi ta svitohliadyi aspekty)], «Вісник Львівського університету: серія історична», вип. 43, с. 134-183.

СУМ, Словник украӥнської мови [Slovnyk ukrainskoi movy], т. 1-11, Київ 1970-1980.

Турчин С. [Turchyn Ye.] (2011), Словник села Тилич на Лемківщині [Slovnyk sela Tylych na Lemkivshchyni], Львів.

Фальковські Я. [Falkovski Yа.] (1935), Село Волосате, Ліського повіта [Selo Volosate, Lis'koho povita), «Літопис Бойківщини», с. 14-28.

Шило Г. [Shylo, Н.] (2008), Наддністрянський ретіональний словник [Naddnistrianskyi regionalnyi slovnyk], Львів.

Янкова Т.С. [Yankova Т. S.] (1982), Дыялектни слоўнік Лоеўшчыны [Dyialektny slovnyk Loievshchyny], Мінск.

Karłowicz J., Kryński A.A., Niedźwiedzki W. (1900-1927), Słownik języka polskiego, t. 1-8, Warszawa.

Nowak K. (2015), Śląskie słownictwo gwarowe dotyczace domów mieszkalnych, zabudowań gospodarczych oraz ich wyposażenia, [в:] Studia Ślaskie, t. LXXVII, Opole, s. 185-200.

SGP, Stownik gwar polskich, pod kier. M. Karasia, J. Reichana, Wrocław-Warszawa-KrakówGdańsk 1979-2004. 